https://doi.org/10.52058/2786-4952-2022-2(7)-581-596

Савченко Ольга Олександрівна кандидат філософських наук, доцент кафедри іноземних мов, Харківський національний університет Повітряних Сил імені Івана Кожедуба, вул. Клочківська, 228, м. Харків, 61045, https://orcid.org/0000-0003-0085-7189

Петрушенко Жанна Володимирівна старший викладач кафедри іноземних мов, Харківський національний університет Повітряних Сил імені Івана Кожедуба, вул. Клочківська, 228, м. Харків, 61045, https://orcid.org/0000-0002-9610-8926

Дерека Ірина Вікторівна старший викладач кафедри соціальногуманітарних дисциплін, Харківський військовий інститут танкових військ НТУ “ХПІ”, вул. Полтавський Шлях, 192, м. Харків, 61000, https://orcid.org/0000-0003-1938-4094

\title{
МОЖЛИВОСТІ ВИКОРИСТАННЯ ПРЕДМЕТНО-МОВНОГО ІНТЕГРОВАНОГО ПІДХОДУ В НАВЧАННІ ФАХІВЦІВ ВІЙСЬКОВОГО ПРОФІЛЮ
}

Анотація. Необхідність здійснювати вільну комунікацію у професійній галузі, можливість користуватися професійною документацією на іноземній мові актуалізує важливість пошуку найбільш оптимальних та доцільних освітніх технологій по формуванню у майбутніх фахівців іншомовної професійнокомунікативної компетенції. Глобалізація світової освіти та зміна освітньої парадигми, в контексті якої іноземна мова розглядається не тільки як засіб передачі інформації, а й як іï отримання, вимагає нових ефективних підходів і методів, форм і способів організації процесу оволодіння мовою. Предметом статті $\epsilon$ предметно-мовне інтегроване навчання (CLIL) як один з інноваційних підходів до організації навчання іноземній мові, що передбачає реалізацію одночасно двох цілей навчання в двох предметних областях - мовної та предметної. Метою статті $є$ виділення різних трактувань сутності даного підходу до навчання, його основних різновидів, принципів та стратегій, та вивчення можливостей й особливостей імплементування CLIL в навчання англійської мови фахівцями військового профілю. В умовах професіоналізації іншомовної підготовки майбутніх військових фахівців актуалізується проблема професійно-орієнтованого навчання іноземної мови, під яким розуміється навчання іноземної мови, що засноване на врахуванні особливостей майбутньої професії. Однією 3 найбільш ефективних $\mathrm{i}$ доцільних для формування іншомовної професійно-комунікативної компетенції у майбутніх військових 
фахівців може стати технологія предметно-мовного інтегрованого навчання, оскільки його застосування актуалізує природне вивчення іноземної мови в процесі професійного спілкування й сприяє підвищенню мотивації, що обумовлено особистим інтересом студентів до професійної тематики. Методика предметно-мовного інтегрованого навчання демонструє інтеграцію рецептивних й продуктивних навичок, де акцентуються читання та аудіювання, функціональність мови, змістовні контексти, а основна увага приділяється розвитку лексичних навичок.

Ключові слова: предметно-мовне інтегроване навчання; компоненти $\mathrm{i}$ принципи CLIL, версії CLIL, етапи впровадження CLIL.

Savchenko Olga Oleksandrivna PhD (Social Philosophy), Associate Professor at the Department of Foreign Languages, Ivan Kozhedub Kharkiv National Air Force University, Klochkivska St., 228, Kharkiv, 61045, https://orcid.org/0000-0003-0085-7189

Petrushenko Zhanna Volodymyrivna Senior teacher at the Department of Foreign Languages, Ivan Kozhedub Kharkiv National Air Force University, Klochkivska St., 228, Kharkiv, 61045, https://orcid.org/0000-0002-9610-8926

Dereka Iryna Viktorivna Senior teacher at the Department of Social Disciplines and Humanities, Kharkiv Military Institute for Tank Troops of National Technical University "Kharkiv Polytechnic Institute", Poltava Way St., 192, Kharkiv, 61000, https://orcid.org/0000-0003-1938-4094

\section{POSSIBILITIES OF USING THE CONTENT AND LANGUAGE INTEGRATED LEARNING IN THE CONTEXT OF A MILITARY UNIVERSITY}

Abstract. The need for free communication in the professional field, the ability to use professional documentation in a foreign language emphasizes the significance to find the most optimal and appropriate educational technologies to develop communicative competencies both in a foreign language and in a professional area. The globalization of world education and shift in the educational paradigm, in the context of which a foreign language is considered not only as a means to transmit information but to receive it as well, requires new effective approaches, methods, forms, and ways of organizing foreign language learning. The subject of the article is subject-language integrated learning (CLIL) as one of the innovative approaches to the organization of foreign language learning, which involves the simultaneous implementation of two learning objectives in two subject areas - linguistic and professional. The goal of the article is to study different understandings of the essence of this approach to language learning, to single out its main versions, principles, and strategies, and to study the capabilities and features of CLIL implementation in teaching English to military professionals. Under the conditions of professionalization 
of foreign language training of future military specialists, the issue of professionallyoriented foreign language teaching is actualized, which means foreign language learning based on taking into account the peculiarities of the future profession. One of the most effective and appropriate techniques to develop communicative competencies both in a foreign language and professional area of future military professionals may become the technology of integrated language learning, as its use actualizes the natural learning of a foreign language for professional communication and increases motivation due to students' personal interest in professional topics. The methodology of subject-language integrated learning demonstrates the integration of receptive and productive skills, which emphasize reading and listening, language functionality, meaningful contexts, and focuses on the development of lexical skills.

Keywords: content and language integrated learning; CLIL components and principles, CLIL versions, CLIL implementation stages.

Постановка проблеми. 3 огляду на сучасні вимоги до випускників вищого військового навчального закладу однією з вимог до їх професійної підготовки $\epsilon$ готовність здійснювати комунікацію в межах загальнокультурного, професійного спілкування, користуватися професійною документацією на іноземній мові, що актуалізує необхідність формування іншомовної компетенції військових фахівців в сфері професійної комунікації, основи якої закладаються в процесі навчання у вищій школі та дозволяють в перспективі ефективно вирішувати професійні завдання в умовах полілінгвального професійного середовища. Оскільки великий відсоток наукової літератури видається англійською мовою, спілкування фахівців в різних формах здійснюється, в основному, на англійській мові, використання інформаційного середовища, детермінованого великою кількістю доступної інформації, здійснюється, в основному, на англійській мові, володіння англійською мовою стає особливо актуальним, що, в свою чергу, загострює питання про необхідність змін у викладанні англійської мови. Виявлені проблеми свідчать про необхідність пошуку найбільш оптимальних та доцільних освітніх технологій по формуванню у майбутніх фахівців іншомовної професійно-комунікативної компетенції, актуальною стає розробка нових ефективних підходів і методів, форм і способів організації процесу оволодіння мовою. Такою технологією $\epsilon$ предметно-мовне інтегроване навчання (англ. CLIL - content and language integrated learning), яке було спочатку визначено в 1994 р. й введено в науковий обіг в 1996 р. Університетом Ювяскюля та Європейською платформою голландської освіти для опису освітніх методів, при яких "предмети викладаються іноземною мовою, фокусуючись на двох цілях, а саме на вивченні змісту і одночасному вивченні іноземної мови" [19].

Аналіз останніх досліджень і публікацій свідчить, що незважаючи на підвищений інтерес дослідників до вивчення різних аспектів іншомовної професійно-комунікативної компетенції дана проблема в контексті підготовки майбутніх військових фахівців залишається маловивченою, хоча питання про 
ефективність застосування технології CLIL для формування іншомовної професійної комунікативної компетенції розглядається в роботах багатьох українських вчених, таких як С. Бобиль, Н.Свтушенко, Ю. Руднік, Ю. Соболь, О. Тарнопольський та інших [1-5].

Проблема застосування предметно-мовного інтегрованого навчання у вищій освіті активно розробляється в наукових працях зарубіжних дослідників (D.Marsh, D. Coyle та інші) $[6-10,12,14,15,18-21,25]$. У зарубіжних вищих навчальних закладах широко використовується інтегроване предметно-мовне навчання, при якому, дисципліни або певні теми в межах даних дисциплін вивчаються іноземною мовою і при цьому переслідується дві мети: вивчення змісту даної навчальної дисципліни і одночасне вивчення іноземної мови. Педагогічні методи предметно-мовного інтегрованого навчання в військовій освіті стали областю дослідження польських дослідників [20].

В Італії на початку 2000-х CLIL розглядався як обов'язкова освітня технологія для ліцеїв та освітніх установ технічного профілю. Впровадження CLIL стало справжнім проривним рішенням для італійської освіти, підтвердивши розуміння CLIL як рушійної сили інновацій, що впливають на всіх учасників освітнього простору. Таким чином, Італія стала в один ряд 3 більшістю інших європейських країн, які вже тривалий час експериментують 3 CLIL [12].

Однак, незважаючи на зростання інтересу дослідників до проблеми використання технології CLIL в українській вищій школі при підготовці кадрів різного профілю, питання формування іншомовної професійно-комунікативної компетенції майбутніх фахівців на основі технології CLIL розроблене недостатньо грунтовно й потребує подальшого дослідження.

Мета статті. Практика показує, що в сучасному військовому університеті іноземна мова як навчальна дисципліна продовжує залишатися ізольованою від вивчення змісту дисциплін професійної підготовки Хоча той факт, що використання технології CLIL в навчанні іноземної. мови фахівців військових спеціальностей може сприяти одночасному вивченню як іноземної мови, так й збільшенню професійних знань, не викликає сумнівів, дана технологія досі не знайшла широкого застосування на практиці, що можна пояснити тим, що на сьогоднішній день питання, пов'язані з практичним використанням технології CLIL стосовно формування іншомовної професійно-комунікативної компетенції майбутніх фахівців військової сфери, розроблені не достатньо повно, що актуалізує мету даного дослідження, яка $€$ - розглянути сутність даного підходу до навчання іноземної мови, деталізувати його принципи та стратегії, а також вивчити особливості та можливості реалізації його застосування в навчальному процесі військового університету.

Виклад основного матеріалу. На початку 21 століття після того, як європейські вчені розробили документ "Common European Framework of Reference for Languages Learning, Teaching, Assessment" (2001p.) [13], в якому була запропонована концепція іншомовної комунікативної компетенції, та 
приєднання України до Болонського процесу в 2005 р., активізувалася робота по проведенню досліджень в сфері проектування національних моделей професійно-орієнтованого навчання іноземної мови в технічних вузах.

Одним 3 інноваційних підходів $\epsilon$ предметно-мовне інтегроване навчання, тут і далі CLIL. Термін CLIL зазнав поширення наприкінці 1990-х років, поступово приходячи на зміну термінам bilingual education та immersion (від англ. immerse - занурювати), в межах яких іноземна мова застосовувалась частково, так до 50\% пояснень надавалось іноземною мовою, або викладення частки матеріалу здійснювалось двома мовами, що давало можливість тим, хто навчався, під час вивчення матеріалу за фахом зануритись в іноземну мову [26]. У 2001 р. метод зазнав істотних змін й, незважаючи на певні труднощі, став успішно впроваджуватися в освітній простір багатьох європейських країн, пропонуючи використовувати і вивчати мову не як самоціль, а як засіб вивчення інших предметів, тобто можна сказати, що CLIL зосереджений в двох напрямках: використання мови, що вивчається, для вивчення та викладання предметного змісту, та іноземної мови одночасно. CLIL не $\epsilon$ новою формою вивчення іноземної мови або предмета - це інноваційна технологія, що поєднує в собі безліч методик, здійснених до CLIL. Слід зауважити, що ці численні методики, наприклад, CBI - Content-based instruction; CBLI - Content-based language instruction; CBLT - Content-based language teaching; Dual-focused language education; TFL - Teaching through a foreign language та низка інших, можна згрупувати в три основні підходи, які найбільш широко застосовуються сьогодні для навчання іноземної мови.
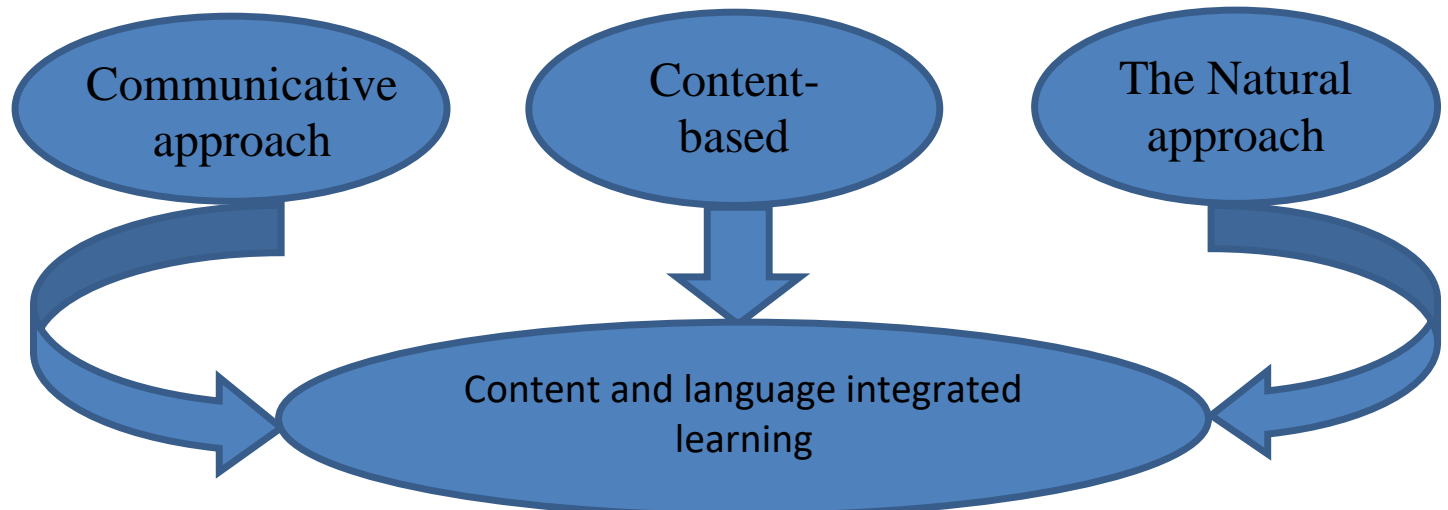

Розглянемо теоретичні основи виникнення і формування даного походу більш детально. Зміни в політичній та соціальній сферах, такі як високий рівень міграції населення, в Свропі й Північній Америці на початку 70-х років минулого століття призвели до серйозних змін в педагогіці та лінгвістиці. У викладанні й вивченні іноземної мови на перший план вийшла взаємодія та комунікація між людьми, а фокус змістився 3 викладача на студента. Основою комунікативного підходу можна вважати теорію комунікативної компетенції, представлену соціолінгвістом Д. Хаймсом [22]. Це було свого роду відповіддю й розвитком теорії Н. Хомського про 
лінгвістичні компетенції, в якій він розмежовує поняття «компетенції», «знання мови» і «володіння мовою», тобто конкретне іiі використання в певних комунікативних цілях та ситуаціях [11]. Д. Хаймс акцентував здатність студента поєднувати граматичні та соціокультурні знання. М. Канале i М. Свейн, які продовжували розвиток теорії Н. Хомского, розмежовували стратегічні, граматичні та соціолінгвістичні компетенцій [10], що дозволило поставити володіння граматикою в більш визначений комунікативний контекст.

3 упевненістю можна сказати, що комунікативний підхід є проривом в лінгводидактиці XX століття, оскільки саме завдяки йому студенти почали сприймати мову в першу чергу як засіб спілкування в реальних життєвих ситуаціях. На даний момент комунікативний підхід є провідним і найбільш поширеним при викладанні іноземної мови, оскільки включає різноманітні інтерактивні завдання, різні форми парної і групової роботи, ігрові методики, передбачає використання пісень і фільмів для занурення в середу і культуру країни мови, що вивчається, широке використання інтернет-ресурсів, що дозволяє розвивати автономність тих, хто навчається, і дає їм можливість самим розширювати комунікативні компетенції у володінні іноземною мовою.

В межах комунікативного підходу сформувався один 3 перших інтегрованих підходів, що включають в вивчення мови елемент змісту - CBI (content-based instructions) [9], в якому акцент зміщується 3 вивчення самої мови на вивчення чогось за допомогою мови. Незважаючи на те, що ідея інтеграції предметного змісту і мови не нова сама по собі, вона існувала $\mathrm{i}$ реалізовувалася в межах методик мовного занурення в школах Канади i США, повсюдне поширення ця ідея отримала пізніше, оформившись в СВА (content-based approach). В межах цієї методики, мова виступає засобом для обговорення предмета вивчення i $\epsilon$ другорядною метою навчання. Однак оволодіння мовою все ж відбувається, завдяки постійному контакту студента 3 предметом та мовою, якою йому пропонується опанувати зміст цього предмета. Таким чином, студенти вивчають предмет, який їм цікавий, але використовуючи не рідну мову, а іноземну, яку вони теж намагаються вивчити, але використовуючи їі швидше, як інструмент розширення знань по предмету $\mathrm{i}$ тим самим розширюючи ще й свої лінгвістичні компетенції. Інші вчені $[17,21]$ вважають, що цій підхід узгоджується з теорією природного підходу (Natural Approach), що був запропонований С. Крашеном, згідно до якої вивчення нового предметного змісту з використанням іноземної мови, дає студентам можливість оволодіти мовою на рівень вище їх поточного рівня, оскільки оволодіння іноземною мовою відбувається набагато ефективніше, якщо мова вивчається в реальних, комунікативно-значущих ситуаціях [23].

Теорія природного підходу була запропонована в кінці 1970 х-початку 1980-х років. Т. Террелом та С. Крашеном, які розмежовували поняття «вивчення мови» (language learning) й «оволодіння мовою» (language acquisition) [24]. С. Крашен стверджував, що здатність оволодіння мовою $\epsilon$ 
підсвідомим процесом, який притаманний приблизно однаково як дітям, так i дорослим, тоді як вивчення мови - це повністю свідомий процес, що супроводжується цілою низкою правил. У контексті теорії природного підходу до вивчення іноземних мов, С. Крашен запропонував п’ять гіпотез [23]:

- гіпотеза про відмінність вивчення мови $i$ оволодіння мовою (Acquisition-Learning Hypothesis), згідно 3 якою існує чітка межа між «засвоєнням» (acquisition), яке С. Крашен розглядав як суто несвідомий процес, і «вивченням» (learning) - що є свідомою дією, причому С. Крашен стверджував, що поліпшення володіння мовою залежить лише від засвоєння, і ні в якому разі не від вивчення;

- гіпотеза про природний порядок (Natural Order Hypothesis), в якій говориться, що мова засвоюється в певному порядку, i що зазначений порядок не змінюється в залежності від індивідуальних особливостей тих, хто її вивчає, і на нього не впливають явні пояснення викладача;

- zinomeза редактора (Monitor Hypothesis), згідно з якою свідомо вивчена мова може служити лише для того, щоб «редагувати» (to monitor language output) мовний матеріал, що продукується, й не може бути джерелом спонтанної мови;

- гіпотеза вхідного матеріалу (Input Hypothesis), згідно з якою, ті, хто вивчають мову, покращують свої знання мови, коли вхідний мовний матеріал (language input), з яким вони працюють, трохи перевищує їхній поточний рівень володіння мовою;

- гіпотеза афективного фільтра (Affective Filter Hypothesis), згідно з якою здатність засвоїти мову тими, хто їі вивчають, обмежена, якщо вони відчувають негативні емоції, такі, як страх або сором, які й «включають» даний фільтр.

Теорія природного підходу до вивчення іноземної мови суттєво вплинула на розвиток лінгводидактики i, разом 3 іншими підходами, деталізованими вище, об'єдналася в таку ефективну педагогічну парадигму як предметно-мовної інтегрований підхід (CLIL).

На сьогоднішній день існує досить велика кількість визначень предметномовного інтегрованого навчання, кожне з яких в тій чи іншій мірі характеризує його багатогранну сутність.

Європейська комісія трактує предметно-мовне інтегроване навчання як вивчення предмету через іноземну мову, що надає ефективні можливості використовувати свої нові мовленнєві навички зараз, а не формувати їх зараз для використання в майбутньому [27].

Ф. Болл, що працює в межах даного підходу в Іспанії, в своїй статті наводить п’ять визначень [7]. Однак, найбільш загальноприйнятим вважається визначення основоположника даного підходу Д. Марша, який в 1994 р. вперше вжив термін content and language integrated learning, який пізніше став офіційною назвою даного підходу, й в даний час використовується в науково-методичній літературі, що видається різними мовами. Д. Марш визначає даний підхід як освітній підхід, при якому предмети або частини предметів викладаються 
іноземною мовою переслідуючи з подвійну мету, а саме вивчення змісту та одночасне вивчення іноземної мови мету: вивчення змісту дисципліни й одночасне вивчення іноземної мови [25]. Для характеристики сутності CLIL Д. Койл [14] розробив схему 4Cs, яка умовно представлена на малюнку нижче.

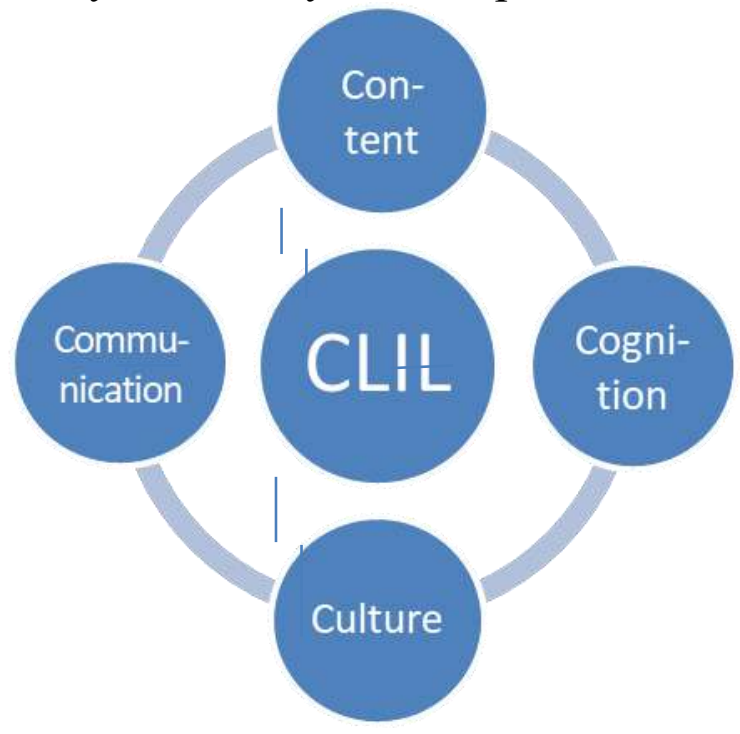

Д. Койл [c. 5] розглядає 4Cs таким чином:

Контент (content) - предмет з усіма темами, що містяться в ньому, при вивченні яких, "здобуваються знання, формуються навички та розвивається розуміння"; зміст має бути взаємопов'язаним з повсякденним життям, і студенти вивчають факти не на основі теоретичної інформації, а на практиці, що підкріплена теорією.

Спілкування (communication) - мова вивчається за допомогою спілкування, але акцент робиться на мову як засіб спілкування; точність не впливає на швидкість мови, хоча й має бути в наявності; студент перебуває в центрі навчального процесу, тому вітається мовленнєва взаємодія за схемами студентстудент, студент-група, група-група.

Пізнання (cognition) - не означає просту передачу інформації від викладача до студента або запам'ятовування пропонованих знань, воно скоріше містить навички мислення вищого порядку (High Order Thinking Skills) i спонукає студентів розвивати особисті способи розуміння.

Культура (culture) або обізнаність про культурні аспекти зобов'язує студентів розширювати свої знання про інші культури, а культурні відмінності вимагають від студентів вибрати необхідні мовленнєві інструменти в ситуаціях, що пов'язані з культурним контекстом.

У межах підходу CLIL цінуються автентичні матеріали, крім того, чотири мовленнєві навички розвиваються паралельно, а саме - рецептивні: аудіювання - яке сприймається як джерело вхідної інформації, що є життєво важливим для вивчення мови; читання - де зміст є одним з основних джерел інформації; а також продуктивні: говоріння - де основна увага приділяється швидкості, а точність розглядається як другорядна навичка; письмо - де основна увага 
приділяється розвитку лексичних навичок, в ході розвитку яких, повторюється граматика. Тобто навчання, побудоване за методикою CLIL, демонструють інтеграцію рецептивних й продуктивних навичок, де акцентуються читання та аудіювання, функціональність мови, змістовні контексти, а основна увага приділяється розвитку лексичних, а не граматичних навичок, і при плануванні типів завдань, вирішальне значення має особистий стиль навчання студентів.

Підхід CLIL має великий дидактичний потенціал, про що свідчить гіпотеза Дж. Каммінза про підвищення рівня формування когнітивної компетенції за рахунок інтенсифікації розумових процесів [17], яка грунтується на когнітивних теоріях білінгвізму, що розглядають внутрішні когнітивні процеси, пов'язані 3 проблемою взаємовідносин мислення й мовлення іноземною мовою. Відомо, що мислення й мова не ізольовані поняття, вони функціонують в нерозривному зв’язку, і втрата даного зв'язку призводить до зниження ефективності як першого, так і другого. Ця гіпотеза має назву BICS/CALP, де BICS (Basic Interpersonal Communicative Skills) - загальна мовна компетенція, а CALP (Cognitive Academic Language Proficiency) - когнітивна мовна компетенція. На основі теорії BICS/CALP Дж. Каммінза побудував двофакторну модель комунікації, яку часто розглядають як теоретичну основу для застосування CLIL у вищій школі.

Важливо також відзначити той факт, що ряд вчених розрізняють hard або strong (content-driven) та soft або weak (language-driven) підходи в контексті CLIL [6, 8, 18].

Strong/Hard CLIL зосереджений на предметному змісті, хоча має місце повне занурення в мову (як зміст дисциплін, які вивчаються, так і освітній простір в цілому), викладання ведеться викладачами спеціальних дисциплін. В межах Weak/Soft CLIL викладання і навчання зосереджені в першу чергу на мові й, отже, орієнтовані на мову, дана модель передбачає, що викладачі мовних предметів проводять заняття, презентуючи мовний матеріал через науковий або професійний контекст.

Останнім часом актуалізується так звана проміжна (mid) - модульна (Modular) модель CLIL, в якій предмет або якась його частина викладаються іноземною мовою з подвійними цілями, тобто навчання сфокусовано й на мові, й на змісті.

Всі ці концепції досить успішно застосовуються у вищій школі сьогодні, але для того, щоб відповідати вимогам предметно-мовного інтегрованого підходу, викладач іноземної мови, або ж викладач того чи іншого спеціального предмета має вносити зміни в свої методологічні принципи роботи, що $\epsilon$ основоположним для CLIL. Впровадження предметно-мовного інтегрованого підходу в навчання, безумовно, має важливий освітній потенціал, що надає йому когнітивні та лінгвістичні переваги.

Зупинимося на деяких можливостях застосування даного підходу до викладання іноземної мови у військовому університеті.

В умовах професіоналізації іншомовної підготовки майбутніх військових фахівців актуалізується проблема професійно-орієнтованого навчання іноземної 
мови, під яким розуміється навчання іноземної мови, що засноване на врахуванні особливостей майбутньої професії, і яке в даний час здійснюється викладачами через комунікативний, проектний, діяльнісний, змішаний та інші підходи. Серед цього різноманіття найбільш ефективною i доцільною для формування іншомовної професійно-комунікативної компетенції у майбутніх військових фахівців може стати технологія предметно-мовного інтегрованого навчання, яка в рамках вищої школи передбачає таке навчання, при якому одночасно відбувається одночасне вивчення предметного змісту профільної дисципліни та іноземної мови, за допомогою якої здійснюється процес навчання.

Особливостями технології CLIL в контексті військового університету є: одночасна подвійна спрямованість процесу навчання (професійна й лінгвістична), тобто іноземна мова інтегрована 3 предметним змістом навчальної дисципліни. При цьому інтеграція може здійснюватися в двох напрямках: (1) коли вивчення іноземної мови включено в програму навчання профільної дисципліни та (2) коли здійснюється співпраця викладача іноземної мови 3 викладачем спеціального предмета, тобто іноземна мова $\epsilon$ засобом вивчення професійних предметів, а не метою навчання. Таким чином, застосування даної технології актуалізує природне вивчення іноземної мови в процесі професійного спілкування, коли професійна комунікація важливіша за граматичну правильність мовлення (якщо помилки не перешкоджають комунікації), що сприяє підвищенню мотивації тих, хто навчається, що обумовлено їх особистим інтересом до професійної тематики.

Особливо важливим $є$ той факт, що застосування технологї CLIL не висуває вхідних вимог до мовних навичок тих, хто навчається, оскільки на заняттях можливе використання матеріалів різної мовної складності. Основною лінгводидактичною одиницею в методиці CLIL $є$ спеціальний текст, на основі вивчення та опрацювання якого досягаються навчальні цілі. Текст як джерело інформації знайомить студента 3 певною темою, а також служить основою лексико-граматичного модуля, що забезпечує засвоєння наукової термінології та певних граматичних і структурно-стилістичних конструкцій. Текст також $\epsilon$ відправною точкою для проведення дискусій та розширення мовного матеріалу по заданій темі, одночасно сприяючи формуванню й активізації комунікативних навичок діалогічного та монологічного мовлення. В якості ресурсної бази текстів і матеріалів для їх складання можна використовувати різні підручники (як приклад можна згадати серію навчальних матеріалів видавництва Express Publishing - Career Paths, які варіюються від рівня A-1 до В1+, а також різноманітні інтернет-ресурси).

На сьогоднішній день найбільш поширеною й часто використовуваної моделлю вивчення мови у військових освітніх установах, $\epsilon$ soft-модель, яка фокусується на іноземній мові та здійснюється, як правило, викладачем іноземної мови на основі тематики предметної дисципліни. Застосування Нard моделі пов'язане 3 певними труднощами, так як згідно 3 теоретичними 
положеннями технології CLIL викладач, що працює за даною технологією, одночасно має задовольняти двом умовам: (1) викладач повинен бути фахівцем в сфері предметної дисципліни й виступати на заняттях в ролі носія спеціальних знань, (2) викладач має володіти іноземною мовою на рівні В2-C1 за шкалою CEFR, що в даний час в Україні є досить проблематичним, що й перешкоджає впровадженню технології CLIL на практиці, оскільки, 3 одного боку, стримуючим фактором $\epsilon$ та обставина, що в більшості вищих навчальних закладів викладачі іноземних мов не мають додаткової професійної спеціалізації, а викладачі, що викладають спеціальні предмети, мають недостатній рівень мовної підготовки, а 3 іншого боку, відсутня можливість широкомасштабного співробітництва викладачів іноземної мови з викладачами спеціальних предметів на постійній основі. Певним виходом можна вважати застосування проміжної "модульної" (Modular) моделі, яка може бути реалізована двома викладачами спільно, при цьому робиться вибір, який 3 розділів вивчати іноземною мовою за допомогою викладача іноземної мови, а які - рідною за допомогою викладачів спеціальних дисциплін.

У будь-якому випадку, при виборі моделі CLIL необхідно враховувати те, що по-перше, студенти мають різнорівневу мовну підготовку, а можливостей внесення глобальних змін до організаційної структури університету немає, що актуалізує необхідність створення гнучкого курсу, який можна легко редагувати та реалізувати як викладачами іноземного мови, які мають базові знання у конкретній предметній галузі, так і викладачами спеціальних предметів, які мають необхідний рівень володіння іноземними мовами для здійснення викладацької діяльності. Таким чином, найбільш підходящою для освітніх організацій вищої освіти моделлю предметно-мовного інтегрованого навчання $\epsilon$ модель з упором на мовну складову («м'яка» (soft) модель), організована за темами дисциплін, що викладаються, з одночасним паралельним викладанням іноземної мови та спеціального предмета, що реалізується за допомогою інноваційних методів викладання іноземної мови у вищій школі, таких як метод інтерактивного навчання, проектний метод, ігровий метод, інформаційний метод та використання інтернет ресурсів.

На початковому етапі застосування цієї технології у хід заняття можна впроваджувати елементи CLIL. Такими елементами можуть бути такі види діяльності та вправи:

пошук аналогів українських термінів у запропонованому тексті (matching);

- виділення ключових слів (keywords spotting);

- складання діаграми зв'язків (mindmaps, spidergrams);

- будування питань (making questions);

- $\quad$ творчі завдання (case studies, roleplays).

Таким чином, при плануванні та проведенні заняття із застосуванням CLIL на початковому етапі застосовується певний алгоритм дій: аналізується та відбирається матеріал, плануються засоби педагогічних комунікацій для 
подальшого практичного застосування. Вибір версії CLIL або їхнє варіювання може стати надзвичайно ефективною моделлю навчання на всіх етапах впровадження даного підходу в освітній процес.

Підсумовуючи вищесказане, можна сформулювати такі дидактичні принципи, що визначають CLIL:

- принцип дуальності (використання рідної та іноземної мов);

- принцип інтеграції іноземної мови та предметного змісту;

- принцип поступового ускладнення змісту;

- $\quad$ принцип спрямованості на оволодіння знаннями з конкретного предмета за допомогою двох мов (рідної та іноземної);

- принцип розвитку мотивації до здатності та готовності використовувати іноземну мову у спеціальних цілях;

- принцип єдності розумової та мовленнєвої діяльності іноземною мовою.

Проаналізувавши наявний досвід вищих навчальних закладів щодо впровадження практики CLIL в освітній простір вищої школи, можна констатувати, що складно знайти універсальне рішення, тому що кожна освітня організація має вибирати найбільш підходящу іiі форму реалізації виходячи з іiі цілей та можливостей. Крім того, на основі існуючих практик очевидно, що повністю скопіювати модель CLIL, прийняту в зарубіжних навчальних закладах, не є можливим через те, що наші освітні реалії специфічні, так само як й освітні цілі, яких ми повинні досягти. Отже, необхідно враховувати той факт, що слід адаптувати цей освітній підхід під специфіку вищої військової школи 3 урахуванням особливостей студентів та викладачів.

Висновки. На основі викладеного вище можна зробити висновок про те, що в контексті військового університету, і особливо беручи до уваги вихідний рівень іноземної мови військових студентів, більш рекомендованою $\epsilon$ «м'яка» версія моделі CLIL, яка фокусує наступні етапи впровадження CLIL у процес навчання іноземної мови:

\section{- огляд та виділення необхідного навчально-методичного матеріалу;}

- розподіл засобів та технік педагогічного спілкування;

- безпосередня реалізація CLIL у процес навчання.

На першому етапі впровадження CLIL у процес навчання мають бути враховані такі педагогічні умови - визначення об'єктів вивчення та відбір навчального матеріалу 3 урахуванням психологічних аспектів когнітивної діяльності та вікових особливостей студентів, оскільки занадто простий чи, навпаки, складний матеріал, що пропонується викладачем для опанування, може вплинути на рівень мотивації студента. На наступних двох етапах розподілу засобів та технік педагогічного спілкування, а також реалізації у процесі навчання необхідні такі педагогічні умови як:

- високий професіоналізм та творча співпраця викладачів професійно-орієнтованих дисциплін та викладачів іноземної мови; 
- стимуляція когнітивної діяльності студентів на всіх етапах заняття;

роботи.

оптимальне поєднання індивідуальних та групових форм

Отже, на етапах планування та застосування предметно-мовного інтегрованого підходу (CLIL) викладачеві рекомендується скласти навчальний стандарт, який включає кілька уроків за однією темою, що вивчаються протягом певної кількості навчальних годин (у відповідності до навчального плану навчального закладу) .

Підсумовуючи вищевикладене, можна зробити висновок, що предметномовне інтегроване навчання в контексті вищої військової школи має задовольняти наступним вимогам:

- предметно-мовне інтегроване навчання має переслідувати двоєдину мету: навчання предметному змісту іноземною мовою та одночасне навчання самій мові;

- в контексті предметно-мовного інтегрованого навчання іноземна мова одночасно має стати об'єктом вивчення й засобом навчання предметної дисципліни;

- предметно-мовне інтегроване навчання має створити особливе пізнавальне середовище, в якому вивчення предметної дисципліни та іноземної мови становить єдине ціле;

- предметно-мовне інтегроване навчання у вищій школі необхідно відрізняти від використання іноземної мови як засобу викладання, оскільки йдеться про паралельне освоєння предметної дисципліни та власне мови;

- різні моделі реалізації предметно-мовного інтегрованого навчання можуть бути використані для реалізації підготовки майбутніх спеціалістів військового профілю, проте найбільш успішною на сьогоднішній день є модель з упором на мовну складову (soft CLIL), спланована відповідно до тематики предметної дисципліни.

\section{Лimepamypa:}

1. Бобиль С. В. Застосування "інтегрованих уроків" у процесі навчання РЯІ / С. В. Бобиль, В. Ю. Тютюнник // Наукові записки Національного університету "Острозька академія". Сер. : Філологічна, 2012. - Вип. 25. - С. 146-148. - Режим доступу: http://nbuv.gov.ua/UJRN/Nznuoaf_2012_25_51.

2. Свтушенко Н. Особливості використання методики предметно-мовного інтегрованого навчання (CLIL) при підготовці студентів-філологів педагогічних ВУЗів / Актуальні питання гуманітарних наук, 2019. - Вип 26, том 1. - С.77-82.

3. Руднік Ю.В. Впровадження методики предметно-мовного інтегрованого навчання: за i проти (світовий досвід) [Електронний pecypc] http://elibrary.kubg.edu.ua/2896/1/ Y_Rudnik_VOU_13_IMMN_PI.pdf

4. Соболь Ю. О. Предметно-мовне інтегроване навчання в технічному університеті / Ю. О. Соболь // Наукові записки [Національного університету "Острозька академія"]. Cер. Філологічна, 2013. - Вип. 33. - С. 319-320. Режим доступу: http://nbuv.gov.ua/UJRN/ Nznuoaf_2013_33_100. 
5. Тарнопольський О. Б. Навчання через зміст, змістовно-мовна інтеграція та іншомовне занурення у викладанні іноземних мов для професійних цілей у немовних вишах / О. Б. Тарнопольський // Іноземні мови, 2011. - № 3. - С. 23-27. - Режим доступу: http://nbuv.gov.ua/UJRN/im_2011_3_4.14.10.2020).

6. Ball, Ph. How do you know if you're practising CLIL? / Ph. Ball // One Stop English: English Language Resources. 2013. Режим доступу: URL:http://www.onestopenglish.com/clil/ methodology/articles/article-how-do-you-know-if-yourepractising-clil/500614.article].

7. Ball, Ph. What is CLIL? // One Stop English: English Language Resources, 2013. Режим доступу:http://www.onestopenglish.com/clil/methodology/articles/article-what-isclil/500453.article

8. Bentley, K. The TKT Course: CLIL Module. Cambridge University Press, 2010. - 128p.

9. Brinton, D. M., Snow, M. A., \& Wesche, M. B. Content-based second language instruction. University of Michigan Press ELT, 2003. - 304 p.

10. Canale, M., Swain, M. Theoretical bases of communicative approaches to second language teaching and testing / Applied Linguistics, 1980, Volume I, Issue 1, Spring. - P. 1-47.

11. Chomsky, N. Aspects of the Theory of Syntax. Cambridge: M.I.T. Press, 1965. - 261 p.

12. Cinganotto, L. CLIL in Italy: A general overview. // Latin American Journal of Content and Language Integrated Learning, 9(2), 2016. - 384 р., Р. 374-400. Режим доступу: https://laclil.unisabana.edu.co/index.php/LACLIL/article/ view/7177/pdf

13. Common European Framework of Reference for Languages Learning, Teaching, Assessment. Council of Europe. 2020. - 278 p. Режим доступу: https://rm.coe.int/commoneuropean-framework-of-reference-for-languages-learning-teaching/16809ea0d4

14. Coyle, D. Developing CLIL: Towards a theory of practice. CLIL in Catalonia. From Theory to Practice. APAC Monographs 6, 2005. - P. 5-29.

15. Coyle, D. CLIL: Content and Language Integrated Learning. Cambridge University Press, 2010. $-184 \mathrm{p}$.

16. Cummins, J. Knowledge, power, and identity in teaching English as a second language / Educating second language children. Cambridge University Press, 1994. - P.33-56

17. Cummins, J. Language, Power and Pedagogy: Bilingual Children in the Crossfire. Clevedon: Multilingual Matters, 2000. - 320 p.

18. Dale, L., Tanner, R. CLIL Activities: A Resource for Subject and Language Teachers. Cambridge University Press, 2012. - 284 p.

19. Darn, S. Content and Language Integrated Learning (CLIL). A European Overview. Режим доступу: https://files.eric.ed.gov/fulltext/ED490775.pdf

20. Gawlik-Kobylińska, M, Lewińska. Content Language Integrated Learning in Polish Higher Military Education. Partnership for Peace Consortium of Defense Academies and Security Studies Institutes, 2014. Vol.13 (3). - P. 105-116. Режим доступу: https://www.jstor.org/stable/26326370?seq=9\#metadata_info_tab_contents

21. Grabe, W., Stroller, F.L. Content-Based Instruction: Research Foundations, 1997. Режим доступу: https://carla.umn.edu/cobaltt/modules/principles/grabe_stoller1997/foundation.pdf

22. Hymes, D. Two types of linguistic relativity / Sociolinguistics. Bright, W. (ed.). The Hague: Mouton, 1966. - P. 114-158.

23. Krashen, S. Principles and Practice in Second Language Acquisition. Alemany Pr.1982. - 212 p.

24. Krashen, S., Terrel, T.D. (1983). The Natural Approach: Language Acquisition in the Classroom. Oxford: Pergamon Press. -196 p.

25. Marsh D., P. Hood, D. Coyle D. CLIL: Content and Language Integrated Learning. Cambridge: CUP, 2010. - 184 p.

26. Marsh, D., Nikula, T. Terminological Considerations Regarding Content and Language Integrated Learning Bulletin suisse de linguistique appliquee, 1998, No. 67, Р. 13-18. Режим доступу: https://files.eric.ed.gov/fulltext/ED422727.pdf 
27. Promoting Language Learning and Linguistic Diversity: An Action Plan 2004-2006. Brussels, 2004. - P. 8-9

\section{References:}

1. Bobyl', S.V., Tyutyunnyk, V.Yu. (2012). Zastosuvannya "intehrovanykh urokiv" u protsesi navchannya RYAI [Using "integrated lessons" in the process of learning Russian as a foreign language]. Naukovi zapysky Natsional'noho universytetu "Ostroz'ka akademiya". Ser.: Filolohichna - Scientific Proceedings of Ostroh Academy National University: Philology Series, 25, 146-148. Retrieved from: http://nbuv.gov.ua/UJRN/Nznuoaf_2012_25_51 [in Ukrainian].

2. Yevtushenko, N. (2019). Osoblyvosti vykorystannya metodyky predmetno-movnoho intehrovanoho navchannya (CLIL) pry pidhotovtsi studentiv-filolohiv pedahohichnykh VUZiv [Peculiarities of the contenct and language integrated learning (CLIL) use in training philology students of pedagogical universities]. Aktual'ni pytannya humanitarnykh nauk - Current Issues of the Humanities, 26 (26), 77-82 [in Ukrainian].

3. Rudnik YU.V. Vprovadzhennya metodyky predmetno-movnoho intehrovanoho navchannya: za i proty (svitovyy dosvid) [Implementation of the content and language integrated learning approach: pros and cons (world experience)]. Retrieved from: http://elibrary.kubg.edu.ua/ 2896/1/ Y_Rudnik_VOU_13_IMMN_PI.pdf [in Ukrainian].

4. Sobol', Yu.O. (2013). Predmetno-movne intehrovane navchannya $v$ tekhnichnomu universyteti [Content and language integrated learning at a Technical university]. Naukovi zapysky Natsional'noho universytetu "Ostroz'ka akademiya". Ser. Filolohichna - Scientific Proceedings of Ostroh Academy National University: Philology Series, 33 (33), 319-320. Retrieved from: http://nbuv.gov.ua/UJRN/Nznuoaf_2013_33_100. [in Ukrainian].

5. Tarnopol's'kyy, O.B. (2011). Navchannya cherez zmist, zmistovno-movna intehratsiya ta inshomovne zanurennya u vykladanni inozemnykh mov dlya profesiynykh tsiley u nemovnykh vyshakh [Learning through content, content and language integration and the immersion in a foreign language while teaching foreign languages for professional purposes in non-language universities] // Inozemni movy - Foreign Languages, 3, 23-27. - Retrieved from: http://nbuv.gov.ua/UJRN/ im_2011_3_4.14.10.2020) [in Ukrainian].

6. Ball Ph. How do you know if you're practising CLIL? / Ph. Ball // One Stop English: English Language Resources. 2013. Retrieved from: URL:http://www.onestopenglish.com/clil/ methodology/articles/article-how-do-you-know-if-yourepractising-clil/500614.article].

7. Ball Ph. (2013). What is CLIL? // One Stop English: English Language Resources. Retrieved from: http://www.onestopenglish.com/clil/methodology/articles/article-what-isclil/500453.article

8. Bentley, K. (2010). The TKT Course: CLIL Module. Cambridge University Press. - 128p.

9. Brinton, D. M., Snow, M. A., \& Wesche, M. B. (2003). Content-based second language instruction. University of Michigan Press ELT. -304 p.

10.Canale, M., Swain, M. (1980). Theoretical bases of communicative approaches to second language teaching and testing / Applied Linguistics, Volume I, Issue 1, Spring. - P. 1-47.

11.Chomsky, N. (1965). Aspects of the Theory of Syntax. Cambridge: M.I.T. Press. - 261 p.

12. Cinganotto, L. (2016). CLIL in Italy: A general overview. // Latin American Journal of Content and Language Integrated Learning, 9(2). - 384 p., P. 374-400. Retrieved from: https://laclil.unisabana.edu.co/index.php/LACLIL/article/ view/7177/pdf

13. Common European Framework of Reference for Languages Learning, Teaching, Assessment. Council of Europe. 2020. - 278 p. Retrieved from: https://rm.coe.int/commoneuropean-framework-of-reference-for-languages-learning-teaching/16809ea0d4

14. Coyle, D. (2005). Developing CLIL: Towards a theory of practice. CLIL in Catalonia. From Theory to Practice. APAC Monographs 6. - P. 5-29.

15. Coyle, D. (2010). CLIL: Content and Language Integrated Learning. Cambridge University Press. -184 p.

16. Cummins, J. (1994). Knowledge, power, and identity in teaching English as a second language / Educating second language children. Cambridge University Press. - P.33-56 
17. Cummins, J. (2000). Language, Power and Pedagogy: Bilingual Children in the Crossfire. Clevedon: Multilingual Matters. -320 p.

18. Dale, L., Tanner, R. (2012). CLIL Activities: A Resource for Subject and Language Teachers. Cambridge University Press. -284 p.

19. Darn, S. Content and Language Integrated Learning (CLIL). A European Overview. Retrieved from: https://files.eric.ed.gov/fulltext/ED490775.pdf

20. Gawlik-Kobylińska, M, Lewińska (2014). Content Language Integrated Learning in Polish Higher Military Education. Partnership for Peace Consortium of Defense Academies and Security Studies Institutes. Vol.13 (3). - P. 105-116. Retrieved from: https://www.jstor.org/stable/26326370?seq=9\#metadata_info_tab_contents

21. Grabe, W., Stroller, F.L. Content-Based Instruction: Research Foundations. (1997). Retrieved from: https://carla.umn.edu/cobaltt/modules/principles/grabe_stoller1997/foundation.pdf

22. Hymes, D. (1966). Two types of linguistic relativity / Sociolinguistics. Bright, W. (ed.). The Hague: Mouton. - P. 114-158.

23. Krashen, S. (1982). Principles and Practice in Second Language Acquisition. Alemany Pr.1982. -212 p.

24. Krashen, S., Terrel, T.D. (1983). The Natural Approach: Language Acquisition in the Classroom. Oxford: Pergamon Press. - 196 p.

25. Marsh D., P. Hood, D. Coyle D. CLIL: Content and Language Integrated Learning. Cambridge: CUP, 2010. - 184 p.

26. Marsh, D., Nikula, T. (1998). Terminological Considerations Regarding Content and Language Integrated Learning Bulletin suisse de linguistique appliquee, 1998, No. 67, P. 13-18. Retrieved from: https://files.eric.ed.gov/fulltext/ED422727.pdf

27. Promoting Language Learning and Linguistic Diversity: An Action Plan 2004-2006. Brussels, 2004. - P. 8-9 